COMMENT OPEN

\title{
Concerns on a new therapy for severe heart failure using cell sheets with skeletal muscle or myocardial cells from iPS cells in
} Japan

\author{
Yoshiki Yui ${ }^{1}$
}

In Japan, a new therapy for severe heart failure using skeletal myocardial sheet is ongoing and a treatment using iPS cells is just about to start. However, I think there are problems and concerns. In this comment, I will express concerns on these treatments. This will be useful and interesting to stem cell researchers and clinical cardiologists.

npj Regenerative Medicine (2018)3:7 ; doi:10.1038/s41536-018-0047-2

Induced pluripotent stem (iPS) cells are a promising source of cells for regenerative medicine, and we have high expectations. Biomedical engineering with cell sheets is an interesting approach for the treatment of severe heart failure.

In this comment, I will express my concerns about an ongoing and upcoming new therapy in Japan for severe heart failure using cell sheets with skeletal myoblasts or iPS cells.

\section{AUTOLOGOUS SKELETAL MYOBLAST SHEETS}

On 1 October of last year (2017) at the 65th Annual Scientific Session of the Japanese College of Cardiology (Osaka), Prof. Y. Sawa (Department of Cardiovascular Surgery, Osaka University) gave a special lecture. The topic was on autologous skeletal myoblast sheets for the treatment of severe chronic heart failure. He also presented a new therapy with induced pluripotent stem (iPS) cells instead of skeletal myoblasts as the next stage of treatment.

I have the following concerns regarding this therapy based on his published article, ${ }^{1}$ the product document https://www.pmda. go.jp/safety/info-services/ctp/0001.html created by Terumo Corporation authorized by PMDA (Pharmaceuticals and Medical Devices Agency, Japan), a council report, ${ }^{2}$ and his lecture.

(1) In the study, the left ventricular ejection fraction (LVEF) ${ }^{3}$ was employed as the primary endpoint.The change in LVEF was classified as improved $(\triangle \mathrm{LVEF} \geq 5 \%)$, unchanged $(5 \%>$ $\Delta \mathrm{LVEF}>-3 \%)$, or worsened $(-3 \% \geq \Delta \mathrm{LVEF})$. The corresponding number of patients were 0,5 , and 2 , each respectively.In Fig. 2 of the paper, ${ }^{1}$ the LVEF between pretreatment and 26 weeks after the surgery is shown, but the statistics were not described. Using the data in the product document https://www.pmda.go.jp/safety/infoservices/ctp/0001.html, I performed a statistical calculation with the paired $t$-test. The two-tailed $P$-value was 0.6985 (not statistically significant). I have two serious questions about this study. First, the LVEF as a primary endpoint is unreliable and inappropriate, because heart failure with preserved ejection fraction exists. ${ }^{4}$ Second, among the 7 patients, 5 were classified as "responders" to this therapy. However, the definition of "responders" to this therapy appears medically inappropriate, because "responders" included those with unchanged LVEF (5 patients) in addition to patients with improved LVEF ( 0 patients). As pointed out in the council report (Page 58), ${ }^{2}$ the fluctuation $(-5-5 \%)$ in LVEF is a measurement error. This council report recommends that $\Delta \mathrm{LVEF} \geq 5 \%$ should be the improvement of cardiac function.

(2) In the product document, the indication for using autologous skeletal myoblast sheets is as follows:

a. Patients with severe heart failure due to ischaemic heart disease.

b. Patients who did not respond to the standard therapies (drugs and interventional devices).

c. NYHA (New York Heart Association) class III or IV

d. LVEF at rest is $35 \%$ or less.

In the above lecture, Prof. Y. Sawa presented 12 cases after 6 months of the operation, and he concluded that, for patients with LVEF less than $30 \%$, this sheet seems to have little effect in improving severe heart failure. Considering the above inclusion criteria (2)-d, the number of patients with the indication seems to be very small.

Currently, the clinical trial with skeletal myoblast sheets is ongoing. In September, 2015 using the above 7 cases, the Terumo Corporation obtained a temporary approval from the Ministry of Health, Labour and Welfare. However, within 5 years, after completing additional 60 cases with ischaemic heart failure, an application for the final approval must be submitted. The superiority of the survival rate compared with 120 cases with standard therapies is required. This requirement by PMDA seems highly plausible. However, this trial is not a placebo-controlled, double-blind RCT (randomized-control trial). Patients backgrounds are different. Even if propensity score matching is used, evaluating the effectiveness of the trial may be difficult.

In Japan, regenerative medicine is controlled by Pharmaceuticals and Medical Devices Act, the Act to Ensure the Safety of Regenerative Medicine, and the Clinical Trial Act. The Clinical Trial

${ }^{1}$ Kyoto, Japan

Correspondence: Yoshiki Yui (yoshikibmw@gmail.com)

Received: 20 November 2017 Revised: 28 February 2018 Accepted: 1 March 2018

Published online: 21 March 2018 
Act was legislated last year (2017) by the Diovan (Valsartan) misconduct, which I pointed out. ${ }^{6,7}$ Under Pharmaceuticals and Medical Devices Act, a fast track conditional approval (conditional time-limited authorization) started. This autologous skeletal myoblast sheets was the first approval.

\section{IPS CELL SHEETS}

On July 19 of last year (2017), there was an official announcement from the Graduate School of Medicine, Faculty of Medicine, Osaka University about a new project by Prof. Y. Sawa involving the treatment of severe heart failure with iPS cells http://www.med. osaka-u.ac.jp/archives/7911. In the statement, it was mentioned that the autologous skeletal myoblast sheets was not effective for more severe heart failure. Hence the use of myocardial cells from iPS cells is being developed alternatively. In the above meeting, Dr. Sawa explained the protocol using iPS cells instead of skeletal myoblasts. However, these iPS cardiomyocytes were not derived from the patient's own cells but were from stocked cells from other donors. Stocked iPS cells from healthy donors with homozygous human leucocyte antigen, for which safety is checked beforehand are going to be used. ${ }^{8}$ This modified strategy with allotransplantation is due to the cost and time issues associated with autologous iPS cells. ${ }^{8}$ This type of iPS cells requires immunosuppressive drugs. The expectation had been raised that autologous cells would be used for the cell sheets. This is apparently not the case and this should be made entirely clear by the team involved. The use of autologous iPS cells is hopefully a future perspective that will be realized.

According to Dr. Sawa and the above statement, he will start this new surgical therapy as early as this year to evaluate the safety of iPS-derived myocardial cells. Unlike other iPS trials, such as those for Parkinson's disease and age-related macular degeneration of the eye, the objective evaluation of improvement of severe heart failure is far more difficult. To obtain a statistically adequate number of patients and assess them during the followup period, an international multicentere trial supported by the Japanese government is absolutely necessary. This trial with iPS cardiomyocyte sheets is interesting and challenging. If properly developed, this iPS therapy would surely open a new era in the treatment of severe heart failure.

Hopefully, before beginning the new therapy with iPS cell sheets, extensive and precise data about ongoing trials with skeletal myoblast sheets will be released.

In conclusion, for trials dealing with severe heart failure, strict statistics, protocols and hard endpoint (death) are necessary:

(1) The primary endpoint should be cardiac and total death.

(2) A placebo-controlled double-blind RCT is ideal.

During a pilot study phase, placebo and double-blind are not necessary. However, at final stage, to prove the effectiveness of the treatment, both are necessary, which will finally lead to the interests of patients.

If hard endpoint (death) and surrogate endpoints ${ }^{9}$ including subjective symptoms are dramatically improved, a placebocontrolled double-blind RCT may become unnecessary.

\section{ADDITIONAL INFORMATION}

Competing interests: The author declares no competing financial interests.

Publisher's note: Springer Nature remains neutral with regard to jurisdictional claims in published maps and institutional affiliations.

\section{REFERENCES}

1. Sawa, Y. et al. Safety and efficacy of autologous skeletal myoblast sheets (TCD51073) for the treatment of severe chronic heart failure due to ischemic heart disease. Circ. J. 79, 991-999 (2015).

2. PMDA. A council report about the myocardial sheet by PMDA (statement of reasons of the fast track conditional approval). http://www.pmda.go.jp/ regenerative_medicines/2015/R20151008001/ 470034000_22700FZX00002_A100_2.pdf (2015).

3. Solomon, S. D., Wu, J., Gillam, L. Echocardiography in Braunwald's Heart Disease (A Textbook of Cardiovascular Medicine) 10th edn, (eds Douglas L. Mann, Douglas P. Zipes, Peter Libby, Robert O. Bonow \& Eugene Braunwald) 179-260 (Elsevier Saunders, 2015).

4. Zile, M. R., Little, W. C. Heart failure with a preserved ejection fraction. in Braunwald's Heart Disease (A Textbook of Cardiovascular Medicine) 10th edn, (eds Douglas L. Mann, Douglas P. Zipes, Peter Libby, Robert O. Bonow \& Eugene Braunwald) 557-574 (Elsevier Saunders, 2015).

5. James, L. J. Jr, Mann, D. L. Clinical Assessment of Heart Failure: in Braunwald's Heart Disease (A Textbook of Cardiovascular Medicine) 10th edn, (eds Douglas L. Mann, Douglas P. Zipes, Peter Libby, Robert O. Bonow \& Eugene Braunwald) 473-484 (Elsevier Saunders, 2015).

6. Yui, Y. Concerns about the Jikei heart study. Lancet 379, e48 (2012).

7. Yui, Y. Prevention of misconduct in clinical trials in Japan. Lancet 384, 1098 (2014).

8. Yui, Y. Questions surrounding iPS cells in Japan. Int. J. Stem Cells 9, 1-2 (2016).

9. O'Connor, C. M. et al. Effect of nesiritide in patients with acute decompensated heart failure. N. Engl. J. Med. 365, 32-43 (2011).

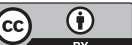

Open Access This article is licensed under a Creative Commons Attribution 4.0 International License, which permits use, sharing, adaptation, distribution and reproduction in any medium or format, as long as you give appropriate credit to the original author(s) and the source, provide a link to the Creative Commons license, and indicate if changes were made. The images or other third party material in this article are included in the article's Creative Commons license, unless indicated otherwise in a credit line to the material. If material is not included in the article's Creative Commons license and your intended use is not permitted by statutory regulation or exceeds the permitted use, you will need to obtain permission directly from the copyright holder. To view a copy of this license, visit http://creativecommons. org/licenses/by/4.0/.

(c) The Author(s) 2018 